\title{
Factors Related to the Utilization of the National Health Insurance Program (JKN) at Batang Toru Community Health Center, South Tapanuli Regency in 2019
}

\author{
Leli Khairani Siregar ${ }^{1}$, Sri Lestari Ramadhani Nasution², Johannes Bastira Ginting ${ }^{3}$, \\ Ermi Girsang ${ }^{4}$ \\ 1,2,3,4 Magister Public Health Study Program, Faculty of Medical, Universitas Prima Indonesia, Medan, \\ Indonesia
}

\section{Abstract}

This study aims to determine the factors associated with the use of the JKN program, namely individual characteristics (age, education, and employment), capability characteristics (availability of health workers and location accessibility), and characteristics of needs (illness perception). The populations in this study are all people who underwent health services at Batang Toru Health Center in South Tapanuli Regency with a total sample of 98 people. Data were collected using a questionnaire and analyzed using the Pearson Correlation test and multiple logistic regression tests. The results showed that there was a significant relationship with age ( $p$ $=0,000)$; education ( $p=0.001)$; occupation $(p=0,000)$; availability of health workers $(p=0,000)$; location accessibility $(p$ $=0,000)$ and pain perception $(p=0,000)$ with the use of the JKN program at Batang Toru Health Center. The results of paper multivariate analysis and modeling showed that the factors that were significantly and dominantly related to the use of the JKN program at Batang Toru Health Center were the availability of health workers, location accessibility factors, and illness perception factors. Thus it was concluded that the availability of health workers, accessibility of location, and perception of pain were significantly and dominantly related to the use of the National Health Insurance (JKN) program at Batang Toru Health Center in South Tapanuli Regency in 2019 of health workers is the most dominant factor and has the biggest influence on the use of the JKN program location accessibility factors and illness perception factors.
Keywords

characteristics;

insurance program;

Batang Toru health

\section{Introduction}

Health services are one form of basic services that are very much needed by the community, so it is very necessary to always be addressed, to realize fast, accurate, and inexpensive services. This business in the health sector has been initiated by the government for a long time, including through PT. Askes and PT. Jamsostek (Persero). PT. Askes and PT. Jamsostek serves civil servants, pensioners, veterans, and private employees. For the poor and underprivileged, the government also provides health insurance, namely through the system of Community Health Insurance and Regional Health Insurance. 
However, these systems are still divided between Askes and Jamsostek, making health costs and quality of service difficult to control. To overcome this problem, 2004 Law no. 40 of 2004 concerning the National Social Security System (SJSN). UU no. 40 of 2004 contains compulsory social security for all residents including National Health Insurance (JKN) through a Social Security Administering Body. JKN emphasizes decent health services for all citizens. According to Law No. 40 of 2004, JKN is held based on the principle of humanity, the principle of benefit, and the principle of social justice for all Indonesian people.

With the JKN, it is hoped that all Indonesian citizens will be protected in a national health system. The National Health Insurance Program (JKN) aims to provide benefits for health services to the community. The challenge in implementing JKN lies not only in the readiness of infrastructure in health services but also the availability of human resources (HR) in the health sector. The availability of facilities and infrastructure, health workers, medical devices, and medicines to support health services is still a problem that can hinder the maximum implementation of national health insurance.

Today's development has included empowerment as one that is prioritized in building a nation. This situation is interpreted as the existence of power or autonomy given by the government to the community in order to be able and independent in determining goodness for themselves, or in other words that there is openness from the government to accommodate various kinds of initiatives from groups that are considered to experience powerlessness or vulnerability (Adiwijaya et al, (2018). Every worker in carrying out their work must receive protection for occupational safety and health in accordance with human dignity and dignity, so that workers feel comfortable and safe working in the company (Marbun, 2020).

Public health center are the pillars of basic services in the health sector so that the public health center plays a very important role in the administration of the National Insurance System. Considering the important role of the public health center in the implementation of this Health Insurance, it is very necessary to have the readiness of the public health center to the available resources and support from various parties in supporting the implementation of this Health Insurance System. So that the establishment of a health center must meet the requirements for location, building, infrastructure, health equipment, workforce, pharmaceuticals, and laboratories (Ministry of Health, 2014). Public health center and JKN are two things that are interrelated and cannot be separated in the health service system in Indonesia. The provision of good health services at a public health center will enable many JKN participants to take advantage of health services. Hsb Maryam (2020) states that the existence of Public Health Center in the community is very important because the Public Health Center are the spearhead of health services provided by local governments. Individual health efforts at Public Health Center are related to sick behavior and treatment seeking behavior in sick people.

Batang Toru Public health center is one of the public health centers located in South Tapanuli Regency, North Sumatra Province which was established in 1974. This Public health center is precisely located in the Wek II sub-district, Batang Toru sub-district, which consists of 3 auxiliary health centers covering 19 villages and 4 sub-districts, and is a public health center with care stay. Based on the researcher's survey, found the low utilization of the JKN program by the community where consumers in terms of age, education, occupation, availability of health workers, distance to service locations, the behavior of officers, and perceptions of illness can influence patients to take advantage of health services, as well as access roads to health centers which can adversely affect the interest in utilizing health services at the Public health center. 
Patient visit data from Batang Toru Health Center, throughout 2018, of 8,737 patients, 3,372 (38.59\%) of whom still did not use health insurance in using health services. From January to June 2019, there were 4,125 patient visits, and only 994 patients used JKN, or it is estimated that around $24 \%$, while the remaining $76 \%$ of patients have not used JKN. This data shows that there is still a low number of patients seeking treatment at Batang Toru Community Health Center who use JKN. Based on the above background, the researchers are interested in conducting a study on "Factors Related to the Utilization of the National Health Insurance Program (JKN) at Batang Toru Health Center, South Tapanuli Regency in 2019".

\section{Research Methods}

This research is a type of quantitative research that is causal associative. Associative research is a study that aims to determine the relationship between two or more variables (Sangaji, 2017). Causal design is useful for measuring the relationships between research variables or is useful for analyzing how a variable affects other variables (Sugiyono, 2017). The research design used in this study is an observational study with a cross-sectional approach, namely by collecting data on the use of the JKN program and collecting data on factors related to the use of the JKN program which includes age, education, occupation, availability of health workers, location accessibility and perception of pain. The samples in this study were patients who visited Batang Toru Public Health Center who met the inclusion criteria. Samples can be selected because they are at the right time and place. The formula used for sample determination in this study uses the Slovin formula in Umar (2017), as follows:

$$
\begin{gathered}
e \dot{i}^{2} \\
1+N i \\
n=\frac{N}{\dot{i}}
\end{gathered}
$$

Information:

$n$ : Sample Size

$N$ :Population

$e$ : Tolerable level of sampling error $(0.1)$

Then:

$$
\begin{aligned}
& 0,1 \dot{i}^{2} \\
& 1+4125 \dot{ } \\
& n=\frac{4125}{\dot{i}} \\
& n=\frac{4125}{42,25} \quad n=97,63 \approx 98
\end{aligned}
$$

Thus, based on the above calculations, the sample size in this study was as many as 98 people.

Based on the various explanations above, the hypotheses to be tested in this study include: (1) There is a relationship between age and the utilization of the National Health Insurance (JKN) program at Batang Toru Health Center, South Tapanuli Regency in 2019. (2) There is a relationship between education and program utilization. National Health Insurance (JKN) at Batang Toru Health Center, South Tapanuli Regency in 2019. (3) There is a work relationship with the use of the National Health Insurance (JKN) program at Batang Toru Health Center, South Tapanuli Regency in 2019. (4) There is a relationship 
between the availability of health workers and utilization of the National Health Insurance (JKN) program at Batang Toru Health Center, South Tap7anuli Regency in 2019.(5) There is a relationship between location accessibility and the utilization of the National Health Insurance (JKN) program at Batang Toru Health Center, South Tapanuli Regency in 2019. (6) There is a relationship between perception of illness and the use of the National Health Insurance (JKN) program at Batang Toru Health Center, South Tapanuli Regency. 2019. (7) Factors that are significantly and dominantly related to the use of the National Health Insurance (JKN) program at Batang Toru Community Health Center, South Tapanuli District in 2019.

\section{Results and Discussion}

Batang Toru Health Center is a Public health center in Batang Toru District, South Tapanulis Regency, North Sumatra Province which is located behind Batang Toru traditional market, precisely in Wek Village, and is included in the type of inpatient administration. Batang Toru Public health center has a working area of $\pm 351.49 \mathrm{~km} 2$ consisting of 23 villages / sub-districts with a population of 29,517 people (Ministry of Health, 2017). The villages farthest from Batang Toru Public health center are Padang Lancat Village (south), Garoga Village (north) and Hapesong Plantation Village (west).

The results of the survey conducted, found that the number of people (residents) who visited Batang Toru Community Health Center during January to June 2019 was 4,125 visits or only $13.97 \%$ of the total population. The low percentage is due to several factors including geographic factors, such as the less strategic distance between the Public health center and residential areas, where there are several villages that are relatively far from the location of the Public health center and must use a motorbike or motorized pedicab as their transportation due to narrow road conditions and the absence of public transportation four wheels to the village.

Based on Basic Data of Public health center Conditions in December 2017, North Sumatra Province (Ministry of Health, 2017), the number of workforce at Batang Toru Health Center in 2017 was 42 people, which are detailed in Table 1 below:

Table 1. Employment Data of Batang Toru Health Center in 2017

\begin{tabular}{clc}
\hline No. & \multicolumn{1}{c}{ Strength } & Amount \\
\hline 1 & General practitioners & 1 \\
\hline 2 & Nurse & 5 \\
\hline 3 & Midwife & 30 \\
\hline 4 & Pharmacy & 1 \\
\hline 5 & Public health & 3 \\
\hline 6 & Health Support Personnel & 2 \\
\hline \multicolumn{2}{r}{ Amount } \\
\hline
\end{tabular}

Based on the workforce data available at Batang Toru Community Health Center, it shows that as many as 29,517 people in Batang Toru District are only served by 1 general practitioner and 41 other health workers.

Data on the age of respondents in this study were grouped into 2 groups, namely groups aged 17-55 years and groups aged over 55 years. Based on the research findings, the frequency distribution of the respondent's age data is summarized in Table 2 below: 
Table 2. Distribution of Age Data Frequency

\begin{tabular}{cccc}
\hline No. & Age & Amount & Percentage (\%) \\
\hline 1 & $17-55$ years & 83 & 84.7 \\
\hline 2 & $>55$ years & 15 & 15.3 \\
\hline Amount & $\mathbf{9 8}$ & $\mathbf{1 0 0}$ \\
\hline
\end{tabular}

Based on Table 2 above, it can be explained that the age data of respondents who were sampled in this study, as many as 83 people $(84.7 \%)$ were between $17-55$ years old while as many as 15 people (15.3\%) were over 55 years old.

Based on the research findings, the frequency distribution of the respondent's gender data in this study is summarized in Table 3 below:

Table 3. Distribution of Gender Data Frequency

\begin{tabular}{|c|c|c|c|}
\hline No. & Gender & Amount & Percentage (\%) \\
\hline 1 & Man & 39 & 39.8 \\
\hline 2 & Women & 59 & 60.2 \\
\hline & Amount & 98 & 100 \\
\hline
\end{tabular}

Based on Table 3 above, it can be explained that the data on the gender of the respondents in this study were 39 people (39.8\%) men and as many as 59 people $(60.2 \%)$ women.

The data on the education level of respondents in this study were grouped into 2 groups, namely low education (elementary to junior high school graduates) and tertiary education (high school to university graduates). Based on the research findings, the frequency distribution of the respondent's education data is summarized in Table 4 below:

Table 4. Distribution of Education Data Frequency

\begin{tabular}{ccccc}
\hline No. & & Education & Amount & Percentage (\%) \\
\hline 1 & Low & & 23 & 23.5 \\
\hline 2 & High & & 75 & 76.5 \\
\hline & Amount & $\mathbf{9 8}$ & $\mathbf{1 0 0}$ \\
\hline
\end{tabular}

Based on Table 4 above, it can be explained that the data on the education level of respondents in this study, as many as 23 people (23.5\%) were classified as low (only elementary school graduates to junior high school graduates) and as many as 75 people (76.5\%) were classified as high (graduates). High school to college).

Respondent job data in this study were grouped into 2 groups, namely not working or housewives and working. Based on the research findings, the frequency distribution of the respondent's occupational data in this study is summarized in Table 5 below:

Table 5. Job Data Frequency Distribution

\begin{tabular}{cccc}
\hline No. & Profession & Amount & Percentage (\%) \\
\hline 1 & Not Working / IRT & 37 & 37.8 \\
\hline 2 & Work & 61 & 62.2 \\
\hline \multicolumn{2}{c}{ Amount } & $\mathbf{9 8}$ & $\mathbf{1 0 0}$ \\
\hline
\end{tabular}


Data on the availability of health personnel was collected through a questionnaire in the form of a set of questions given to respondents. Furthermore, from the results of the respondents' answers, the data on the availability of health workers in this study were grouped into 2 groups (criteria), namely less available and available. Based on the research findings, the data frequency distribution of the availability of health personnel in this study is summarized in Table 6 below:

Table 6. Frequency Distribution of Health Personnel Availability Data

\begin{tabular}{clcc}
\hline No. & Availability of Health Workers & Amount & Percentage (\%) \\
\hline 1 & Less Available & 14 & 14.3 \\
\hline 2 & Available & 84 & 85.7 \\
\hline \multicolumn{2}{c}{ Amount } & $\mathbf{9 8}$ & $\mathbf{1 0 0}$ \\
\hline
\end{tabular}

Based on Table 6 above, it can be explained that the availability of health workers at Batang Toru Community Health Center according to the opinion or assessment of respondents, as many as 14 people (14.3\%) thought that they were not available, and as many as 84 people $(85.7 \%)$ thought they were available. These results indicate that the majority $(85.7 \%)$ of respondents thought that health workers were available at Batang Toru Community Health Center.

Location accessibility data was collected through a questionnaire. Location accessibility data are grouped into 2 groups (criteria), namely not easy and easy. Based on the research findings, the frequency distribution of the location accessibility data in this study is summarized in Table 7 below:

Table 7. Location Accessibility Data Frequency Distribution

\begin{tabular}{clcc}
\hline No. & Location accessibility & Amount & Percentage (\%) \\
\hline 1 & Not easy & 35 & 35.7 \\
\hline 2 & Easy & 63 & 64.3 \\
\hline \multicolumn{2}{c}{ Amount } & $\mathbf{9 8}$ & $\mathbf{1 0 0}$ \\
\hline
\end{tabular}

Based on Table 7 above, it can be explained that the accessibility to the location of Batang Toru Health Center according to the respondents' opinion, as many as 35 people $(35.7 \%)$ were classified as difficult criteria, and as many as 63 people $(64.3 \%)$ were classified as easy criteria. These results indicate that the majority $(64.3 \%)$ of respondents in this study thought that accessibility to the location of Batang Toru Community Health Center was classified as easy criteria.

Pain perception data were collected through a questionnaire and grouped into 2 groups (criteria), namely not understanding and understanding. Based on the research findings, the frequency distribution of pain perception data in this study is summarized in Table 8 below:

Table 8. Distribution of Frequency of Pain Perception Data

\begin{tabular}{cccc}
\hline No. & Perception of Pain & Amount & Percentage (\%) \\
\hline 1 & Do not understand & 17 & 17.3 \\
\hline 2 & Understand & 81 & 82.7 \\
\hline & Amount & $\mathbf{9 8}$ & $\mathbf{1 0 0}$ \\
\hline
\end{tabular}


Based on Table 8 above, it can be explained that the perception of pain according to the respondent's opinion or assessment, as many as 17 people $(17.3 \%)$ did not understand the concept of illness, and as many as 81 people (82.7\%) understood the concept of illness. The above results indicate that the majority of respondents $(82.7 \%)$ in this study understood the concept of pain.

Data on the use of the National Health Insurance Program (JKN) were collected through a questionnaire which was then grouped into 2 groups (criteria), namely not utilizing and utilizing. Based on the research findings, the data frequency distribution of the JKN program utilization in this study is briefly summarized in Table 9 below:

Table 9. Distribution of the JKN Program Utilization Data Frequency

\begin{tabular}{ccccc}
\hline No. & Use of the JKN Program & Amount & Percentage (\%) \\
\hline 1 & Less & & 22 & 22.4 \\
\hline 2 & Good & & 76 & 77.6 \\
\hline & & Amount & $\mathbf{9 8}$ & $\mathbf{1 0 0}$ \\
\hline
\end{tabular}

Based on Table 9 above, it can be explained that of the 98 research respondents, there were 22 people $(22.4 \%)$ who were under the category of underutilizing the JKN program, and as many as 76 people $(77.6 \%)$ who made good use of the JKN program.

Bivariate analysis was performed using the Pearson Product Moment Correlation test (Pearson Correlation) with the help of the SPSS program. Bivariate analysis was carried out to answer the hypothesis in this study, namely the relationship between age, education, occupation, availability of health workers, location accessibility and perception of pain partially (separately) on the use of the JKN program at Batang Toru Health Center, South Tapanuli District in 2019. using the Pearson Correlation test with the help of the SPSS program about the relationship between age and the use of the JKN program, summarized in Table 10 below:

Table 10. Age Relationship with the Use of the JKN Program

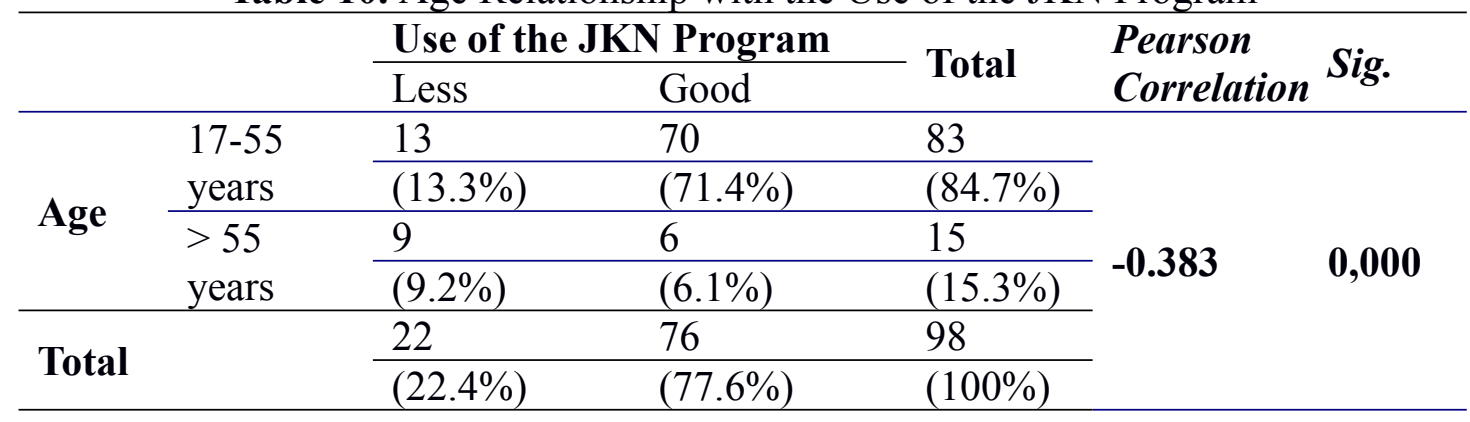

Based on Table 10 above, it can be explained that the results of the cross tabulation between age factors and the use of the JKN program, from 83 people $(84.7 \%)$ of respondents aged $17-55$ years, as many as 13 people (13.3\%) did not take advantage of the program. JKN and as many as 70 people $(71.4 \%)$ made good use of the JKN program. Meanwhile, of the 15 respondents (15.3\%) who were over 55 years old, $9(9.2 \%)$ did not take advantage of the JKN program and 6 people $(6.1 \%)$ made good use of the JKN program. The results of the correlation test obtained the Pearson Correlation value of 0.383 with a Sig or probability $(\mathrm{p})$ value of 0.000 . Since the $\mathrm{p}$ value $=0.000<0.05$,

The results of the relationship between education and the use of the JKN program using bivariate analysis using the Pearson Correlation test with the help of the SPSS program are summarized in Table 11 below: 
Table 11. The Relationship between Education and the Use of the JKN Program

\begin{tabular}{|c|c|c|c|c|c|c|}
\hline & \multicolumn{2}{|c|}{ Use of the JKN Program } & \multirow{2}{*}{ Total } & \multirow{2}{*}{$\begin{array}{c}\text { Pearson } \\
\text { Correlation }\end{array}$} & \multirow{2}{*}{ Sig. } \\
\hline & & Less & Good & & & \\
\hline \multirow{4}{*}{ Education } & & 11 & 12 & 23 & \multirow{6}{*}{0.337} & \multirow{6}{*}{0.001} \\
\hline & Low & $(11.2 \%)$ & $(12.3 \%)$ & $(25.5 \%)$ & & \\
\hline & & 11 & 64 & 75 & & \\
\hline & High & $(11.2 \%)$ & $(65.3 \%)$ & $(76.5 \%)$ & & \\
\hline \multirow{2}{*}{ Total } & & 22 & 76 & 98 & & \\
\hline & & $(22.4 \%)$ & $(77.6 \%)$ & $(100 \%)$ & & \\
\hline
\end{tabular}

Based on Table 11 above, it can be explained that the results of the cross tabulation between the educational factors on the use of the JKN program, of the 23 people $(25.5 \%)$ whose education was classified as low (SD-SLTP graduates), as many as 11 people $(11.2 \%)$ underutilized the JKN program and 12 people (12.3\%) made good use of the JKN program. Meanwhile, of the 75 respondents $(76.5 \%)$ whose education was classified as high (high school-college graduates), $11(11.2 \%)$ did not take advantage of the JKN program and $64(65.3 \%)$ took advantage of the JKN program. well. The results of the correlation test obtained the Pearson Correlation value of 0.337 with a Sig or probability (p) value of 0.001 . Since the $p$ value $=0.001<0.05$.

The results of the bivariate analysis using the Pearson Correlation test with the help of the SPSS program regarding the relationship between work and the use of the JKN program are summarized in Table 12 below:

Table 12. Employment Relationship with the Use of the JKN Program

\begin{tabular}{|c|c|c|c|c|c|c|}
\hline & \multicolumn{2}{|c|}{ Use of the JKN Program } & \multirow{2}{*}{ Total } & \multirow{2}{*}{$\begin{array}{c}\text { Pearson } \\
\text { Correlation }\end{array}$} & \multirow{2}{*}{ Sig. } \\
\hline & & Less & Good & & & \\
\hline \multirow{4}{*}{ Profession } & Does not & 1 & 36 & 37 & \multirow{6}{*}{$-0,369$} & \multirow{6}{*}{$\mathbf{0 , 0 0 0}$} \\
\hline & work & $(1.0 \%)$ & $(36.8 \%)$ & $(37.8 \%)$ & & \\
\hline & Work & 21 & 40 & 61 & & \\
\hline & & $(21.4 \%)$ & $(40.8 \%)$ & $(62.2 \%)$ & & \\
\hline \multirow{2}{*}{ Total } & & 22 & 76 & 98 & & \\
\hline & & $(22.4 \%)$ & $(77.6 \%)$ & $(100 \%)$ & & \\
\hline
\end{tabular}

Based on Table 12 above, it can be explained that the results of the cross tabulation between work factors and the use of the JKN program, of the 37 people (37.8\%) who are classified as unemployed (including IRT) as many as 1 person (1.0\%) who do not use the program. JKN and as many as 36 people $(36.8 \%)$ made good use of the JKN program. Meanwhile, of the 61 people (62.2\%) who were classified as working, 21 people $(21.4 \%)$ did not take advantage of the JKN program and $40(40.8 \%)$ made good use of the JKN program. The results of the correlation test obtained the Pearson Correlation value of 0.369 with a Sig or probability (p) value of 0.000 . Since the $p$ value $=0.000<0.05$,

The results of the relationship between the availability of health personnel and the use of the JKN program using bivariate analysis using the Pearson Correlation test with the help of the SPSS program are summarized in Table 13 below: 
Table 13. The Relationship between the Availability of Health Workers and the Utilization of the JKN Program

\begin{tabular}{|c|c|c|c|c|c|c|}
\hline & \multicolumn{2}{|c|}{ Use of the JKN Program } & \multirow{2}{*}{ Total } & \multirow{2}{*}{$\begin{array}{c}\text { Pearson } \\
\text { Correlation }\end{array}$} & \multirow{2}{*}{ Sig. } \\
\hline & & Less & Good & & & \\
\hline \multirow{4}{*}{$\begin{array}{c}\text { Availability } \\
\text { of Health } \\
\text { Workers }\end{array}$} & Less & 13 & 1 & 14 & \multirow{6}{*}{0.689} & \multirow{6}{*}{$\mathbf{0 , 0 0 0}$} \\
\hline & Available & $(13.3 \%)$ & $(1.0 \%)$ & $(14.3 \%)$ & & \\
\hline & Available & 9 & 75 & 84 & & \\
\hline & Avallade & $(9.2 \%)$ & $(76.5 \%)$ & $(85.7 \%)$ & & \\
\hline \multirow{2}{*}{ Total } & & 22 & 76 & 98 & & \\
\hline & & $(22.4 \%)$ & $(77.6 \%)$ & $(100 \%)$ & & \\
\hline
\end{tabular}

Based on Table 13 above, it can be explained that the results of the cross tabulation between the factors of the availability of health workers on the use of the JKN program, of the 14 people $(14.3 \%)$ who stated that they were not available, as many as 13 people $(13.3 \%)$ did not take advantage of the JKN program. and as many as 1 person $(1.0 \%)$ who made good use of the JKN program. Meanwhile, of the 84 people $(85.7 \%)$ who stated that they were available, $9(9.2 \%)$ did not take advantage of the JKN program and 75 people (76.5\%) made good use of the JKN program. The results of the correlation test obtained the Pearson Correlation value of 0.689 with a Sig or probability $(p)$ value of 0.000 . Since the $p$ value $=0.000<0.05$,

The results of the analysis regarding the relationship between location accessibility and the use of the JKN program using bivariate analysis using the Pearson Correlation test with the help of the SPSS program are summarized in Table 14 below:

Table 14. The Relationship between Location Accessibility and the Use of the JKN Program

\begin{tabular}{|c|c|c|c|c|c|c|}
\hline & & \multicolumn{2}{|c|}{ Use of the JKN Program } & \multirow{2}{*}{ Total } & \multirow{2}{*}{$\begin{array}{l}\text { Pearson } \\
\text { Correlation }\end{array}$} & \multirow{2}{*}{ Sig. } \\
\hline & & Less & Good & & & \\
\hline \multirow{3}{*}{$\begin{array}{l}\text { Location } \\
\text { accessibility }\end{array}$} & Not & 15 & 20 & 35 & \multirow{4}{*}{0.365} & \multirow{4}{*}{$\mathbf{0 , 0 0 0}$} \\
\hline & easy & $(15.3 \%)$ & $(20.4 \%)$ & $(35.7 \%)$ & & \\
\hline & Easy & $\frac{7}{(7,1 \%)}$ & $\frac{56}{(57.2 \%)}$ & $\frac{63}{(64.3 \%)}$ & & \\
\hline \multicolumn{2}{|l|}{ Total } & $\begin{array}{c}22 \\
(22.4 \%)\end{array}$ & $\begin{array}{c}76 \\
(77.6 \%)\end{array}$ & $\begin{array}{c}98 \\
(100 \%)\end{array}$ & & \\
\hline
\end{tabular}

Based on the data in Table 14 above, it can be explained that the cross tabulation results between the location accessibility factors and the use of the JKN program, from 35 people $(35.7 \%)$ of respondents who thought or stated that accessibility to the location of Batang Toru Community Health Center was classified as a difficult category, there were as many as 15 people $(15.3 \%)$ who were categorized as underutilizing the JKN program and as many as 20 people $(20.4 \%)$ who were classified as using the JKN program well. Meanwhile, of the 63 respondents $(64.3 \%)$ who thought or stated that the accessibility to Batang Toru Community Health Center was in the easy category, there were 7 people (7.1\%) who did not take advantage of the JKN program and 56 people (56.2\%) who make good use of the JKN program. The results of the correlation test obtained the Pearson Correlation value of 0,365 with a Sig value or probability (p) of 0.000 . Because the value of $\mathrm{p}=0.000<0.05$, statistically the fifth hypothesis is accepted, so it can be concluded that there is a relationship between the location accessibility factor and the use of the JKN program at Batang Toru Public Health Center, Tapanuli Regency in 2019. 
The results of the analysis of the relationship between the perception of pain and the use of the JKN program using bivariate analysis through the Pearson Correlation test with the help of the SPSS program are summarized in Table 15 below:

Tables 15. The Relationship between Pain Perceptions and the Use of the JKN Program

\begin{tabular}{|c|c|c|c|c|c|c|}
\hline & \multicolumn{2}{|c|}{ Use of the JKN Program } & \multirow{2}{*}{ Total } & \multirow{2}{*}{$\begin{array}{c}\text { Pearson } \\
\text { Correlation }\end{array}$} & \multirow{2}{*}{ Sig. } \\
\hline & & Less & Good & & & \\
\hline & Do not & 12 & 5 & 17 & \multirow{4}{*}{0.529} & \multirow{4}{*}{$\mathbf{0 , 0 0 0}$} \\
\hline Perception & understand & $(12.2 \%)$ & $(5.1 \%)$ & $(17.3 \%)$ & & \\
\hline of Pain & Understand & $\begin{array}{c}10 \\
(10.2 \%)\end{array}$ & $\begin{array}{c}71 \\
(72.5 \%)\end{array}$ & $\begin{array}{c}81 \\
(82.7 \%)\end{array}$ & & \\
\hline Total & & $\frac{22}{(22.4 \%)}$ & $\begin{array}{c}76 \\
(77.6 \%)\end{array}$ & $\frac{98}{(100 \%)}$ & & \\
\hline
\end{tabular}

Based on Table 15 above, it can be explained that the results of the cross tabulation between the perception of pain factors and the use of the JKN program, of 17 people $(17.3 \%)$ whose perceptions of illness were classified as not understanding, there were 12 people $(12.2 \%)$ who were less took advantage of the JKN program and 5 people $(5.1 \%)$ who made good use of the JKN program. Meanwhile, of the 81 people $(82.7 \%)$ who were classified as understanding, as many as 10 people (10.2\%) did not take advantage of the JKN program and 71 people $(72.5 \%)$ who made good use of the JKN program. The results of the correlation test obtained the Pearson Correlation value of 0.529 with a Sig or probability (p) value of 0.000 . Since the $p$ value $=0.000<0.05$,

Multivariate analysis was carried out to determine the relationship between age, education, occupation, availability of health personnel, location accessibility and perception of illness simultaneously with the use of the National Health Insurance (JKN) program at Batang Toru Health Center, South Tapanuli District in 2019. Multivariate analysis was tested with using multiple logistic regression tests with the help of the SPSS program. In the multiple logistic regression model with the backward method, the variables included in the modeling are those that have a Sig. $<0.25$ from the results of the bivariate analysis.

The results of the analysis and multivariate modeling 1 (attachment) obtained the results, namely the age factor $(\mathrm{Sig}=0.195)$; education $(\mathrm{Sig}=0.380)$; occupation $(\mathrm{Sig}=$ 0.142 ); availability of health personnel ( $\mathrm{Sig}=0.001)$; locsi accessibility ( $\mathrm{Sig}=0.083)$; and perception of pain ( $\mathrm{Sig}=0.039$ ); So that this modeling still has to be continued in multivariate modeling 2 where the variables or factors with the highest significance value are excluded one by one from the modeling. After multivariate modeling 2 (the variable released was education), it was found that the insignificant values were age ( $\operatorname{Sig}=0.126$ ); occupation $(\mathrm{Sig}=0.156)$; and location accessibility $(\mathrm{Sig}=0.089)$, so it is still necessary to do multivariate modeling 3 where the work variable is excluded from the modeling because it has the highest significant value.

Tables 16. Results of Multivariate Analysis 4, Relationship of Availability of Health Workers Location Accessibility and Pain Perception with the Use of the JKN Program

Omnibus Tests of Model Coefficients

\begin{tabular}{ccccc}
\hline & & Chi-Square & df & Sig. \\
\hline Step 1 & Step & 58,265 & 3 & 0,000 \\
\hline & Block & 58,265 & 3 & 0,000 \\
\hline
\end{tabular}




Model $\quad 58,265 \quad 3 \quad 0,000$

Based on the data in Table 16 above, it can be explained that the joint correlation between the availability of health personnel, location accessibility and pain perception with the use of the JKN program is obtained by a Chi-Square value of 58.265 with a Sig or probability ( $p$ ) value of 0.000 . Because the value of $p=0.000<0.05$, it can be concluded that the factors of health personnel availability, location accessibility and pain perception simultaneously have a significant correlation or relationship with the use of the National Health Insurance (JKN) program at Batang Toru Public health center, South Tapanuli District. in 2019.

Tables 17. Logistic Regression Determination Coefficient (Multivariate 4)

\begin{tabular}{lccc}
\hline Step & -2 Log likelihood & Cox \& Snell R Square & Nagelkerke R Square \\
\hline 1 & 46,111 & 0.448 & 0.684 \\
\hline
\end{tabular}

Based on the data in Table 4.17 above, the Nagelkerke R Square value or the logistic regression determinant coefficient is 0.684 which means the factors of health personnel availability, location accessibility and pain perception simultaneously and significantly contribute $68.4 \%$ to the utilization of the Guarantee program. National Health (JKN) at Batang Toru Health Center, South Tapanuli District in 2019. Based on the data in Table 4.17 above, the Nagelkerke R Square value is obtained or a logistic regression determinant coefficient of 0.684 which means the factor of health personnel availability, location accessibility and pain perception simultaneously and significantly contributed $68.4 \%$ to the utilization of the National Health Insurance (JKN) program at Batang Toru Community Health Center, South Tapanuli District in 2019.

Table 18. Results of Multivariate Modeling 4 Variables Availability of Health Workers, Location Accessibility and Pain Perception with the Use of the JKN Program

\begin{tabular}{lccccc}
\hline & $\boldsymbol{B}$ & $\boldsymbol{S E}$ & Wald & Sig. & $\boldsymbol{E x p}(\boldsymbol{B})$ \\
\hline $\begin{array}{l}\text { Availability of } \\
\text { Health Workers }\end{array}$ & 4,991 & 1,269 & 15,472 & 0,000 & 147,111 \\
\hline $\begin{array}{l}\text { Location } \\
\text { accessibility }\end{array}$ & 1,709 & 0.822 & 4,324 & 0.038 & 5,525 \\
\hline $\begin{array}{l}\text { Perception } \\
\text { Sick }\end{array}$ & 2,814 & 0.866 & 10,572 & 0.001 & 16,680 \\
\hline
\end{tabular}

Based on the data in Table 4.18 above, it can be explained that the results of multivariate modeling 4 indicate that the variable or factor of labor availability has a Wald value of 15.472 with a Sig or probability (p) value of $0.000<0.05$; the location accessibility factor has a Wald value of 4.324 with a Sig or probability (p) value of 0.038 $<0.05$; and the disease perception factor has a Wald value of 10.572 with a Sig or probability (p) value of $0.001<0.05$. Based on these values, it can be concluded that the availability of health personnel, location accessibility and perception of illness are dominant factors and are significantly related to the utilization of the National Health Insurance (JKN) program at Batang Toru Health Center, South Tapanuli District in 2019. 


\section{Conclusion}

Based on the results of the research findings and analysis carried out, the following conclusions were obtained: (1) There is a significant relationship between age and the use of the National Health Insurance (JKN) program at Batang Toru Health Center, South Tapanuli Regency in 2019. (2) There is a significant relationship. There is a significant relationship between the education factor and the utilization of the National Health Insurance (JKN) program at Batang Toru Health Center, South Tapanuli Regency in 2019. (3) There is a significant relationship between work factors and the utilization of the National Health Insurance (JKN) program at Batang Toru Health Center, South Tapanuli Regency. 2019. (4) There is a significant relationship between the availability of health personnel and the use of the National Health Insurance (JKN) program at Batang Toru Community Health Center, South Tapanuli Regency in 2019. (5) There is a significant relationship between the location accessibility factor and the utilization of the National Health Insurance (JKN) program at Batang Toru Community Health Center, South Tapanuli Regency in 2019. (6) There is a significant relationship between the perceived sickness factor and the utilization of the National Health Insurance (JKN) program at Batang Toru Health Center, South Tapanuli Regency in 2019.

The results of multivariate analysis and modeling, show that the factors that are significantly and dominantly related to the use of the National Health Insurance (JKN) program at Batang Toru Health Center, South Tapanuli District in 2019 are the availability of health personnel, location accessibility factors and pain perception factors. The availability of health personnel is the most dominant factor and has the greatest influence on the utilization of the National Health Insurance (JKN) program at Batang Toru Public Health Center, Tapanuli Regency in 2019.

\section{References}

Adiwijaya, S., et al. (2018). Empowerment Pattern for Thalasemi Patients in Dr. Soetomo Hospital Surabaya (Study of the Association of Parents with Thalassemia Indonesia, Surabaya). Budapest International Research and Critics Institute-Journal (BIRCIJournal), P. 289-298.

Ariska, N., Witcahyo, E., dan Istiaji, E. 2016. Analisis Demand Masyarakat Pesisir terhadap Kepesertaan pada Jaminan Kesehatan Nasional di Kecamatan Puger Kabupaten Jember Tahun 2016. Artikel Ilmiah Hasil Penelitian Mahasiswa. Universitas Jember.

BPJS. 2014. Peraturan Badan Penyelenggara Jaminan Sosial Nomor 1 Tahun 2014, tentang Penyelenggaraan Jaminan Kesehatan.

Effendi, F. 2016. Keperawatan Kesehatan Komunitas: Teori dan Praktek dalam Keperawatan. Jakarta: Salemba Medika.

Hidana, R., Shaputra, R., dan Maryati, H. 2018. Faktor-Faktor yang Berhubungan dengan Pemanfaatan Pelayanan Kesehatan oleh Pasien Luar Wilayah di Public health center Tanah Sareal Kota Bogor Tahun 2018. Promotor: Jurnal Mahasiswa Kesehatan Masyarakat. 1(2): 105-115.

Hsb Maryam, S., Santosa, H. and Asfriyati. (2020). Relationship of Family Income and Family Support with Maternal Reference in Pregnant Women in Pantai Cermin BEmONC, Langkat District, 2019. Budapest International Research and Critics Institute (BIRCI-Journal) : Humanities and Social Sciences, 486-493. 
Irawan, B., dan Ainy, A. 2018. Analisis Faktor-faktor yang Berhubungan dengan Pemanfaatan Layanan Kesehatan pada Peserta Jaminan Kesehatan Nasional di Wilayah Kerja Public health center Payakabung, Kabupaten Ogan Ilir. Jurnal Ilmu Kesehatan Masyarakat. 9(3): 189-197.

Kementerian Kesehatan Republik Indonesia. 2015. Profil Kesehatan Indonesia. Jakarta: Kementerian Kesehatan Republik Indonesia.

Kementerian Kesehatan Republik Indonesia. 2017. Data Dasar Public health center Provinsi Sumatera Utara, Kondisi Desember 2017. Jakarta: Kementerian Kesehatan Republik Indonesia.

Kurniawan, D., Abadi, M.Y., dan Nurhayani. 2018. Faktor-Faktor yang Mempengaruhi Masyarakat dalam Pemanfaatan Jaminan Kesehatan Nasional di Wilayah Kerja Public health center Tamalanrea Jaya Kota Makassar. http://digilib.unhas.ac.id/upload_files/temporary/DigitalCollection.pdf. Diakses 14 November 2019.

Logen, Y.. Balqis, dan Darmawansyah. 2015. Faktor-Faktor yang Berhubungan dengan Pemanfaatan Pelayanan Kesehatan Oleh Pemulung di TPA Tamangapa. Repository Unhas. Universitas Hasnuddin Makassar. http://repository.unhas.ac.id/handle/123456789/14461. Diakses 10 November 2019.

Marbun, J. (2020). Juridical Analysis of the Occupational Safety and Health Management System in the Company. Budapest International Research and Critics InstituteJournal (BIRCI-Journal), P. 895-901.

Napirah, M.R., Rahman, A., dan Tony, A. 2016. Faktor-Faktor yang Berhubungan dengan Pemanfaatan Pelayanan Kesehatan di Wilayah Kerja Public health center Tambarawa Kecamatan Poso Pesisir Utara Kabupaten Poso. Jurnal Pengembangan Kota. 4(1): 29-39.

Notoatmodjo, S. 2016. Promosi Kesehatan dan Perilaku Kesehatan. Jakarta: Rineka Cipta.

Peraturan Presiden Nomor 111 Tahun 2013 tentang Perubahan atas Pepres No. 12 tahun 2013 tentang Jaminan Kesehatan

Peraturan Presiden Nomor 12 Tahun 2013 tentang Jaminan Kesehatan.

Pratiwi, A., dan Raharjo, B.B. 2017. tentang Pemanfaatan Pusat Layanan Kesehatan (Puslakes) Universitas Negeri Semarang. Higeia Journal of Public Health Research and Depelopment. 1(4): 49-60.

Putri, A.E. 2016. Paham JKN, Jaminan Kesehatan Nasional. Jakarta: Friedrich Ebert Stiftung.

Rumengan, D.S.S., Umboh, J.M.L., dan Kandou, G.D. 2015. Faktor-Faktor yang Berhubungan dengan Pemanfaatan Pelayanan Kesehatan Pada Peserta BPJS Kesehatan di Public health center Paniki Bawah Kecamatan Mapanget Kota Manado. JIKMU, Suplemen. 5(1): 88-100.

Sangaji, E.M.S. 2017. Metodologi Penelitian Pendekatan Praktis dalam Penelitian. Yogyakarta: Andi.

Sugiyono. 2017. Metode Penelitian Kuantitatif, Kualitatif dan R\&D. Bandung: Alfabeta.

Trihono. 2016. Manajemen Public health center Berbasis Paradigma Sehat. Jakarta: Sagung Seto.

Umar, H. 2017. Riset Pamasaran, dan Perilaku Konsumen. Jakarta: Gramedia Pustaka Utama.

Undang-Undang Nomor 36 Tahun 2009 tentang Kesehatan.

Undang-Undang Nomor 40 tahun 2004 tentang Sistem Jaminan Sosial Nasional (SJSN).

Wardana, B.K., dan Suharto. 2017. Hubungan Pendidikan dan Pengetahuan Peserta BPJS di Kelurahan Rowosari dengan Pemanfaatan Pelayanan Kesehatan di Public health center Rowosari. 